THE CRIMINALIZATION OF MIGRATION, DETENTION CENTRES, AND THEIR

PORTRAYAL IN THE MEDIA

By

Huda Shaikh, B.A.(Hons), Ryerson University, 2017

\author{
A Major Research Paper \\ presented to Ryerson University \\ in partial fulfilment of the requirements for the degree of \\ Master of Arts \\ in the program of \\ Immigration and Settlement Studies
}

Toronto, Ontario, Canada, 2019

(C) Huda Shaikh, 2019 


\section{AUTHOR'S DECLARATION FOR ELECTRONIC SUBMISSION OF A MAJOR RESEARCH PAPER (MRP)}

I hereby declare that I am the sole author of this Major Research Paper. This is a true copy of my $\mathrm{MRP}$, including any required final revisions.

I authorize Ryerson University to lend this MRP to other institutions or individuals for the purpose of scholarly research.

I further authorize Ryerson University to reproduce this MRP by photocopying or by other means, in total or in part at the request of other institutions or individuals for the purpose of scholarly research.

I understand that my MRP may be made electronically available to the public.

Huda Shaikh 


\title{
THE CRIMINALIZATION OF MIGRATION, DETENTION CENTRES, AND THEIR \\ PORTRAYAL IN THE MEDIA
}

\author{
Huda Shaikh, 2019 \\ Master of Arts 2019 \\ Immigration and Settlement Studies \\ Ryerson University
}

\begin{abstract}
This paper highlights the ways in which political ideologies and the media influence the securitization of borders which in turn results in and continues the cycle of the criminalization of migration. The literature review looks briefly at the development of Canadian policies towards migrants, and the way that international treaty obligations shape this. It will also look at role of the media in the creation of a moral panic, resulting in a mass fear of migrants. This is used as justification for immigration detention centres and the human rights violations within them. I employ a brief content analysis and examine the messages twelve popular media articles portray to Canadians about the centres. I find that recent articles about Canadian immigration detention centres can be divided into four themes: "How They Work", "Public Opposition", "Not as Bad as the U.S." and "Prison-like Conditions". I conclude with policy recommendations and areas for future research with an emphasis on the need to develop effective, rights-based policies for incoming migrants.
\end{abstract}

Key words: Crimmigration, securitization, moral panics, policy, immigration detention centres, human rights, refugee rights, media 


\section{ACKNOWLEDGMENTS}

First, I would like to thank my supervisor, Dr. Dan Horner, for his valuable guidance, support and patience as I developed this project and throughout its progress. I am grateful for Dr. Horner's commitment to working with me and guiding me when I needed him. I would also like to thank my second reader, Dr. Nima Naghibi for her important input to this project. I would like to acknowledge the other faculty in the ISS program whom I had the honour of learning from over the past year.

Thank you to my parents, Muhammad and Farah for their endless love and encouragement. None of this would be possible without your sacrifices and support. Additionally, I am extremely thankful to my husband, Hamza — thank you for always supporting me, believing in me, and encouraging me even at my lowest, I could not have done it without you. Also, thank you to Sahar for the constant support, partnership and friendship over the past year. You helped make the days go by. Finally, a special thank you to the rest of my family and friends for their unwavering love and support.

From The Holy Quran

"verily, with every hardship there comes ease" [94:6] 


\section{TABLE OF CONTENTS}

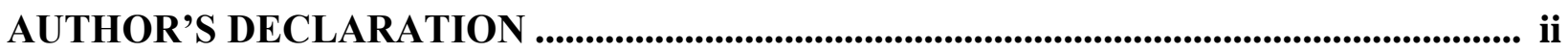

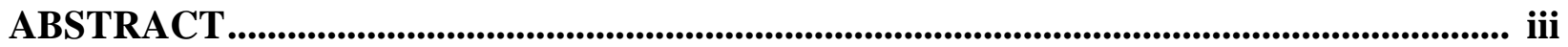

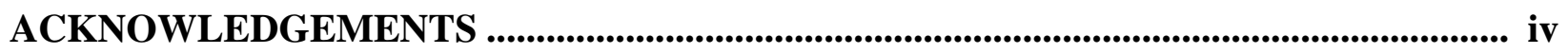

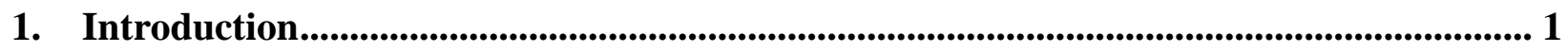

2. Theoretical Framework.......................................................................................................... 5

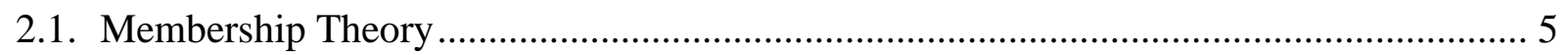

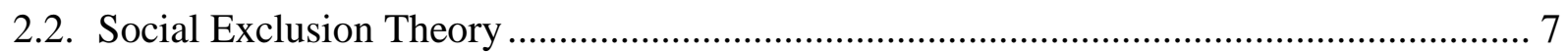

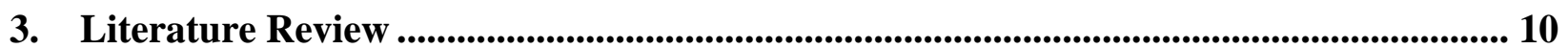

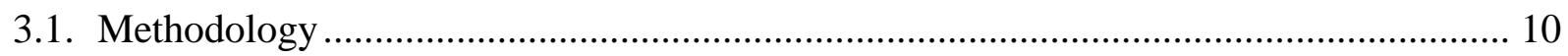

3.2. Globalization: The Link to the Securitization of Borders...............................................11

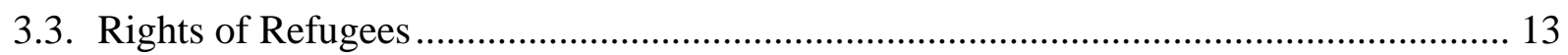

3.4. Political and Media Discourses: The Exaggerated "Fear" \& Moral Panics ................... 15

3.5. Detainment Centres as Prisons............................................................................... 20

4. Content Analysis ....................................................................................................................................... 26

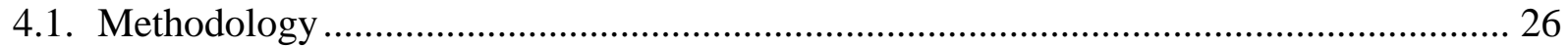

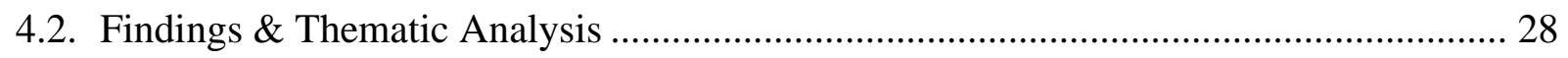

i. "How They Work" ............................................................................................ 28

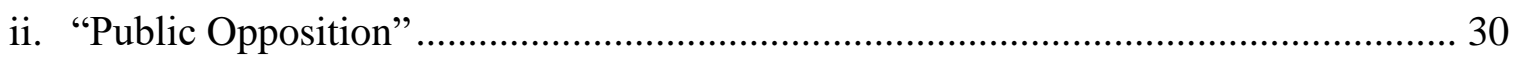

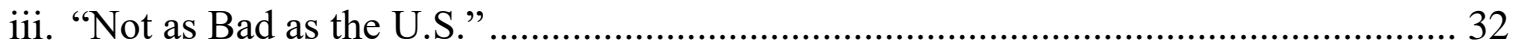

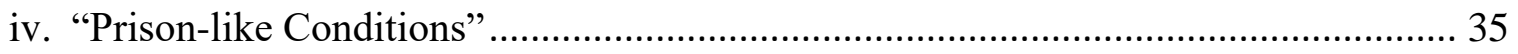

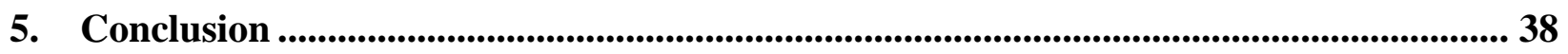

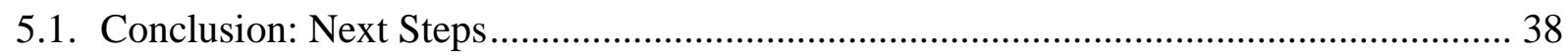

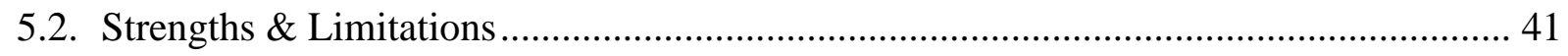

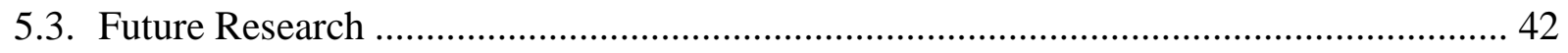

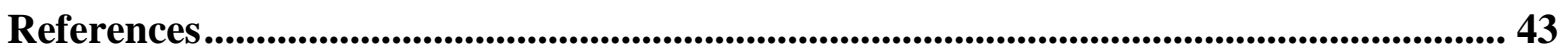

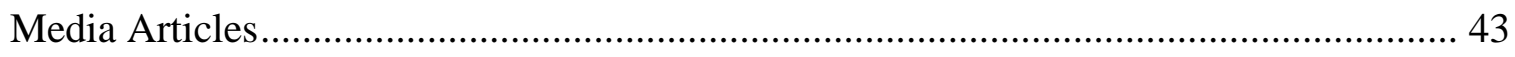

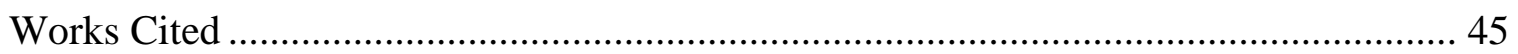




\section{Introduction}

In an era of securitization of borders, there is an increased merger of criminal and immigration law. Both rely heavily on membership theory and social exclusion theory since both criminal and immigration law are systems of inclusion and exclusion; they categorize people as "innocent" versus "guilty", or "legal" versus "illegal" (Stumpf, 2006) and use these terms to determine who is an insider or outsider. Both criminal and immigration law allow certain members to be within society freely, whilst placing physical and institutional restrictions on others. Immigration law uses criminal sanctions, such as detention, to determine immigration penalizations and punish immigration violations while criminal law uses immigration sanctions, such as deportation, to punish criminal violations.

With concerns around national security on the rise, political and ideological discourses are used to criminalize racialized migrants, causing non-status migrants to undergo enhanced security screening and to be detained and deported if they are thought to pose a threat to society. In this way, criminal law is used in lieu of immigration to punish those thought to be a risk because it is cheaper and more convenient to detain and deport suspected-usually racialized— "criminals" than it is to try them in court. This management of immigration that resembles the management of criminals is defined as "crimmigration" (Stumpf, 2006). However, the absence of habeas corpus and other legal rights provided to criminals in immigration matters, despite similar sanctions of detention, depicts a gap in the institutional process.

Political and ideological discourses that label racialized migrants as criminals are used to justify increased border securitization. Amin-Khan (2015) and Menjivar (2014) show that there were multiple policy acts in both the USA and Canada intended to criminalize migrants once globalization and industrialization progressed. These policies were followed by many others in the 
several years leading up to, and after the attacks of September 11, which will be discussed in this paper, highlighting the long-existing links between migration and security. The media and news outlets are perceived as objective and accurate means of information. Therefore, when one event is discussed over and over on all different channels and all different times, people are bound to view this information as important. Thus, internalizing the messages the media is providing without noticing the sensationalistic manners in which they are being reported becomes common. The excessive coverage of a certain event or group by politicians and media alike then create and disseminate a moral panic or "mass fear" of migrants. The media coverage is constantly shaping and reshaping the views and knowledge people have about certain people, crime, the criminal justice system, and what needs to be done in order to protect society.

The practice of creating policies and laws that criminalize migration can lead to extreme and inhumane procedures such as the indefinite detainment of non-status migrants attempting to claim asylum in Canada. According to the Canadian Border Services Agency (CBSA), there were over 6,605 people detained in immigration detention centres in 2017-18, up from 4,248 a year earlier. Furthermore, there were over 1,830 migrants detained in jails in 2017-18, compared to the 971 in 2016-17 (Bensadoun, 2019). It is also important to note that there were over 110 minors held in detention centres in 2018-19, a 51\% drop from 2014-15 (Browne, 2019). Although the number of minors in detention have decreased, it is clear that Canada continues to detain more and more adults each year. Parents with children must decide if they would like their children to be detained with them or placed in foster-care; the decision usually results in family separation. In fact, fathers are by default, held separately from mothers and children. In addition, the CBSA reported that $49 \%$ of detainees were held between 25-48 hours and 40-99 days. Meanwhile, 3.8\% of detainees were held for more than 99 days. Interestingly, the CBSA estimates it costs taxpayers 
over $\$ 310$ per day to detain a non-citizen (Bensadoun, 2019). This is important to note because in comparison, Ontario Works provides a single person with a housing subsidy of approximately \$348 per month. Research continues to show the negative long-term effects of detention on both adults and minors due to the inhumane conditions and procedures, family separation, and lack of knowledge or information provided about the detainment conditions or timeframes. The comparison between immigration detention centres and prisons will be highlighted in this paper.

My research aims in this paper are two-fold. The literature review aims to critically explore how political, ideological and media discourses that label racialized migrants as criminals can be used to rationalize increased border securitization. This will be done by linking the theoretical frameworks of membership theory and social exclusion theory to hegemonic discourses and analyzing their practical outcomes. For instance, I briefly examine the role globalization plays in the increase of border securitization and criminalization of migration. Simultaneously, this paper analyzes the role of politicians and the media in forming a moral panic in which migrants are constructed as a challenge to the societal order that needs to be solved. It will further explain how this increased securitization and criminalization can lead to the validation of extremely inhumane procedures such as the indefinite detainment of non-status migrants in immigration detention centres in Canada, which have been proven to have long-term effects on the mental and physical well-being of migrants attempting to flee asylum. The research being conducted in this project is significant because it aims to highlight the ways in which changing hegemonic discourse have the power to influence and rationalize momentous, yet contentious policies. It aims to accentuate the power that globalization, and the words of politicians and the press have in prompting national consensus. 
The second aim is to conduct a brief content analysis in which I examine multiple Canadian media coverage of detention centres to uncover what is being said about them and to identify reoccurring themes among the media portrayal of the centres. It aims to understand if the information portrayed about detention centres in the media is justifying or denouncing the use of detention centres and if it describes their conditions. This is important for several reasons. For instance, through the examination of the media, it can be explored as to whether these centres can be labelled as sites of criminalization and human rights violations of migrants. In other words, the media outlets may be used as primary evidence depicting if and how these centres are used as sites of criminalization. From this, assertions about the advantages and disadvantages of the messages can be made, and gaps in the reporting can be identified.

This research paper is divided into the following sections. I first discuss my theoretical framework, membership theory and social exclusion theory, to identify the basis of crimmigration policies. I discuss my methodology followed by the role of globalization in shifting the national agenda from pro-migration to national security. I map out the human rights promised to asylum seekers and follow this with a discussion around the role of politicians and the media in the criminalization process of migrants by creating a dominant discourse viewing migrants as a "crisis" to society. I critically identify the ways in which immigration detention centres violate the proposed rights promised to migration and compare the conditions to prisons. I then conduct a brief content analysis and examine twelve Canadian media articles about detention centres. Here I discuss the most common themes found in the articles and the messages they provide to Canadian readers. I conclude with recommendations on how Canada can reduce its use of immigration detention centres and protect the human rights of non-status migrants attempting to seek asylum in Canada, followed by some points for future research. 


\section{Theoretical Framework}

\subsection{Membership Theory}

Discussions shaped by a few important theoretical frameworks conclude that Membership Theory essentially describes the ways in which social cohesion is achieved within groups through common individual attitudes and behaviours. One is considered to be a member of a certain group or society if their attitudes and behaviours are deemed acceptable to the existing members of the group to the point where attachments can be made (Clark, 2006, Friedkin, 2004). Being accepted as a member of an organization aligns with theories of social inclusion and feelings of belonging. However, those who are denied membership into a group, organization, or society, are often denied due to superficial, often racist criteria. Durlauf (1997) suggests that Membership Theory of Inequality is based on the three general propositions as followed (p.1):

1. Individual preferences, beliefs, and opportunities are strongly influenced by one's memberships in various groups. Such groups may be fixed, such as race, or may be determined by the economy or society, such as neighbourhoods, schools, or firms.

2. Positive interaction effects occur between members of a given group, so that group level influences generate common outcomes among group members.

3. Greater societal stratification by income, race, education, or language leads to divergence in group characteristics which results in greater cross-section inequality and decreased social mobility (Durlauf, 1997, p.2).

Propositions 1 and 2 can be looked at as generic principles that determine membership entry into a group and the systems upon which they operate. However, proposition 3 highlights the ways in which some members of society are not permitted to be members of a group. For the purposes of this paper, it can be seen how immigration laws and status in a country can be examined in terms 
of Membership Theory. The role of the press in reinforcing "acceptable" members remains critical. Furthermore, it is falls on the government to "grant" membership into a country based on their own criteria. The work of Durlauf (2007) Ibrahim (2005) and Stumpf (2006) can be used as the guiding framework of membership theory and the role of the government in converging immigration and criminal law.

According to Stumpf (2006), Membership Theory plays a huge role in criminal and immigration law because both systems act as gatekeepers of membership in society; they both determine whether an individual should be included or excluded from our society based on whether they are worthy of inclusion in the national community. Criminal law assumes membership in society, and strips it from individuals who commit serious crimes, while immigration law assumes non-membership and grants membership based on strict and mostly inflexible criteria. Meanwhile, the role of the media in reiterating and reinforcing this view is considerable because the creation of moral panics through sensationalism results in a public consensus of who should and should not be a member of society. Membership Theory is based on the idea that positive rights arise from a social contract between the government and the people. Only members and beneficiaries of the social contract can make claims against the government and are entitled to its protectionsmeaning the government may act outside of the contract's constraints against individuals who are non-members or "aliens". Whomever the current government deems acceptable into a nation is then thus accepted by society, family, employers, etc. and consequently, membership is flexible based on the decisionmaker's view of who deserves it.

The purpose of this paper is to examine the shift in penology from rehabilitation to harsher motivations such as retribution, deterrence (Amin-Khan, 2015), incapacitation, and how the expressive power of the state results in criminal sanctions for non-criminal migrants (Ibrahim, 
2005; Stumpf, 2006). In this instance, the state expresses its moral condemnation both for the crime through criminal punishment and for the individual's status as a noncitizen offender by using its sovereign power to impose sanctions of detention for predicted crimes and by criminalizing immigration violations. This combination of criminal and immigration law to determine acceptable members in society is referred to by Stumpf (2006) as the "crimmigration crisis" (p.377). This paper aims to use this theoretical framework to discuss the state's role in the racial divide between which migrants are and are not permitted to be members in Canada. It also aims to shed light on how the state and media together allow the merger of criminal and immigration law; with the use of criminal sanctions for immigration violations without giving migrants the same due process promised to alleged criminals before and during detainment despite similar conditions between immigrant detention centres and prisons. The role of the media in reinforcing the state's racist framework by disseminating a mass fear of immigration aids in the creation of a public consensus towards immigrant detention centres and the binary between "member" and "non-member" of society.

\subsection{Social Exclusion Theory}

Social Exclusion Theory is a sociological theory that aims to understand the conditions of those regularly excluded from broader society. It is understood as "describing both the structures and the dynamic process of inequality among groups in society which, over time, structure unequal access to critical resources that determine the quality of membership in society and ultimately produce and reproduce a complex of unequal outcomes" (Galabuzi \& Teelucksingh, 2010, p. 9). This paper draws upon the work of Caidi \& Allard (2005), Clark (2007), and Galabuzi \& Teelucksingh (2010) to emphasize the importance of social inclusion and community building in positive mental health and integration process. Social exclusion is systemically produced and 
maintained by institutions which aim to keep their members included and non-members excluded. In the case of immigrants, social exclusion is often produced by those in power and members of society who are against the migration of non-white, non-Christian people into their nation. This purposeful exclusion allows the dominant hegemonic society to remain in power while isolating, deterring and frowning upon the coloured "other".

There are four main aspects of social exclusion: economic exclusion which is the unequal or lack of access to forms of livelihood; exclusion from civil society which includes a disconnection through legal sanctions, institutional mechanisms or systemic discrimination based on race and other factors; exclusion from social goods which is society's failure to provide for the needs of particular groups - including sanctions that deter discrimination; and exclusion from social production which includes the denial of opportunity to practice equally in society (Galabuzi, 2006 as cited in Galabuzi \& Teelucksingh, 2010, p.11). In any case, the purpose of social exclusion is to reinforce social inequalities and maintain the advantages and power of the hegemonic social group, while depriving and limiting life chances of other groups. This social exclusion is a product of the membership framework determined by the state. In essence, social exclusion is a consequence of membership as those who are considered non-members by the state and the media are socially excluded from society and its institutions.

Plenty of research examines the benefits of social inclusion on the integration and settlement of newcomers in a given nation. This is because it assists in the formation of familiarity amongst and within other immigrant groups, strong social networks, and valuable and relatable bonds that are essential in feeling socially included, leading to successful and easier integration in society (Ashutosh, 2011; Clark, 2007; Kozey, 2015; Zhuang, 2015). The importance of social networks as sources of information and guidance for vulnerable populations is also widely 
discussed in literature (Caidi \& Allard, 2005; Galabuzi \& Teelucksingh, 2010). Social networks assist in mediating access to information and resources, contributing to a better understanding and navigation of institutions for newcomers that may help ease their integration process. Galabuzi \& Teelucksingh (2010) describe social inclusion as "being embedded in relationships, partnerships and networks that can be used to enhance positive outcomes or, on the negative side, impede access to opportunity either through social closure or by virtue of its absence" (p. 6). Social inclusion is vital in integration as it allows members of the community to feel welcomed and valuable because new immigrants are able to form meaningful networks and social ties, participate in society, and experience environments that are similar to their transnational identity, reducing feelings of isolation and fear of the new.

It is well known that illegalized migrants are accused of "jumping the queue", "stealing" jobs/resources from "rightful citizens" and are often linked to criminality. Obviously, for migrants that are detained in immigration holding centres, either at entry or at some point during their stay in the country, developing ties and feeling socially included in society is impossible. In fact, migrants in these centres are purposely literally excluded from society. Sometimes, they only have immediate family and a few friends as support for financial, emotional, and other problems. Magalhaes, Carrasco, \& Gastaldo (2010) argue that the effect of migration status on the mental health of undocumented migrants are enormous as many individuals describe their constant fear of "being caught" or deported, which may result in anxiety and paranoia. Furthermore, excessive media coverage that depicts them as unwelcome criminals results in increased feelings of isolation. Many have labelled their experiences as "degrading" and "unliveable" (p.5). Illegalized migrants also present signs of trauma, PTSD, chronic stress, depression, and physical illnesses associated with stress, often from experiences in the homeland, or during migration. For the purposes of this 
paper, the theoretical approach of social exclusion is used in comparison to social inclusion, to highlight the purpose and effects of socially excluding racialized migrants by creating a binary between perceived accepted and unaccepted members of society in the form of common discourse in the political agenda and media representations, as well as their literal separations from society as they are held in detention centres.

\section{Literature Review}

\subsection{Methodology}

This paper is largely an exploratory work and thus relies heavily on analyzing existing literature. There is no limit to how much literature will be used for this project, as the purpose is to conduct a qualitative meta-analysis review. It will review subjective or evaluative research to identify and highlight old and new themes and concepts. It aims to understand the given research on the topic and determine a greater understanding. This is because there is a vast amount of literature that explores the links between political and media discourse on policy developmentmuch of it focuses specifically on border securitization. In order to draw legitimate connections between these concepts, the work of scholars that have looked at longitudinal research and cause and effect relationships is essential. Further, due to the nature of this paper, theoretical frameworks such as Membership Theory, trial by media, Social Exclusion Theory and other researched and developed analytical concepts are better suited to highlight the effects of political and ideological discourses on policy development and imposition. Some research questions the literature review attempts to answer are: What are the ways in which political and ideological discourses increase the public support for the securitization of borders? How can the media be responsible for creating a moral panic which further feeds into the justification of increasing border security? In what ways 
is the detainment process of non-status migrants similar to the criminal process of alleged/convicted criminals in Canada?

The literature for this research will be found using multiple online databases. These include Google Scholar, Ryerson University Library and Archive Database (RULA), and government and non-profit websites such as the webpage for the Canadian Council for Refugees, the CBSA, and NeverHome Canada. This paper will also examine criminal and immigration rights and laws found in the Canadian Criminal Code, the Canadian Charter of Rights and Freedoms, the Immigration and Refugee Protection Act, and the United Nation's Universal Declaration of Human Rights. Further, this paper will examine some case law found on CanLII, such as $R$. v. Singh (1985) and Chaudhary v. Canada (2015)

\subsection{Globalization: The Link to the Securitization of Borders}

Though this paper examines political and media discourses that formulate the securitymigration nexus, it is important to briefly mention that there are considerable links between the effects of globalization on the securitization of borders. Several scholars, including Amin-Khan (2015), Ibrahim (2005), and Toğral (2011), argue that the concept of border security expanded in conjunction with the growth of the global market system. The purpose of globalization is to facilitate the expansion of the global economic market and to remove the barriers to the circulation of capital across borders. Tied to neoliberalism, globalization encourages the privatization of many economic activities that were once in the public sphere for the sake of individual or private capital growth and increased efficiency. This was an important factor that created instability in the Global South, resulting in an influx of migrants to the Global North as well as displacement within the Global South (Amin-Khan, 2015). A significant consequence of globalization included the rise of border securitization that targeted migrants in Western nations. 
During and after the Cold War, states used security to focus on external threats that could give rise to war. So, neoliberalism and the demise of the welfare state called for securitization of borders around the world (Toğral, 2011). A growing push by elites called to cut back on the social services provided to immigrants and other marginalized people. There was a fear that migrants would threaten the nation's way of life and existing structure and thus, migration began being viewed primarily as a security issue by the nation. Ibrahim (2005) finds that the increased globalization of markets led to the rise of security concerns regarding migrants, raising questions of how to provide the state with the tools to protect its interests. The focus on the individual led to the shift in emphasis from human rights to human security and rising levels of migration created a backlash, which governments responded to with increased security. Furthermore, the attacks of September 11, 2001 and fears of terrorism caused public concern and insecurities towards migrants to reach its climax, legitimizing official logic to strengthen border security (Amin-Khan, 2015; Fekete, 2004; Ibrahim, 2005).

There were also increased public fears in the nation of losing national, cultural, and collective identity, having to support immigrants who become unemployed or could not find work, and the pressure placed on resources, such as jobs, healthcare, and educational opportunities by those displaced from the Global South and other nations (Amin-Khan, 2015; Menjivar, 2014). Karyotis (2011) references Lavenex (2001) who refers to this logic as 'realist policy frame' which "involves making some aspects of perceived reality more salient in discourse in such a way to promote a particular problem definition...moral evaluation, and or treatment recommendation" (p.13). Those in power used their positions to shape, reproduce and perpetuate discourses through 'new racism' (Bigo, 2002; Ibrahim, 2005; Toğral, 2011) as they continued to subtly use "modern" racism in attempts to preserve nation identity and unity. Toğral (2011) argues that “...the 
substitution of 'racial differences' by cultural ones have reproduced new regimes of justification for the subordination and exclusion of certain groups of people, and 'has modernized racism and made it respectable"' (p.224). In this case, modern racism involved the state blatantly linking traits of criminality and terror to specific migrant groups, without outright offending the groups in ways that modern liberalism could call out. The attempts included identifying and discouraging the “'destabilizing' and 'damaging' effects of other cultures” (Toğral, 2011, p.220), particularly of Muslims and Arabs post the September 11 attacks. The role of politicians and the media in this will be further explored in the following section.

\subsection{Rights of Refugees}

Before examining the role of politicians, the media, and detention centres in violating the rights of refugees and not living up to Canada's commitments, it is first necessary to map out the proposed rights refugees have. Immigrant and refugee rights are protected under multiple laws/acts in Canada. For instance, according to section 3(2) subsections (d) and (e) of the Canadian Immigration and Refugee Protection Act (IRPA) (2001), the objectives of the act include "to offer a safe haven to persons with a well-founded fear of persecution..." and "to establish fair and efficient procedures that will maintain the integrity of the Canadian refugee protection system, while upholding Canada's respect for the human rights and fundamental freedoms of all human beings".

In addition, the landmark case of $R$. v. Singh set the standards for Canadian Charter rights to be applied to refugees. In 1985, Singh who was a refugee claimant from India, was denied refugee status in Canada and the Immigration Appeal Board ordered him to be deported back to India. Under the Immigration Act, the application for refugee status was made by filling the paperwork, claims, and documentation. However, a lack of oral hearing where the applicant could 
present their case was challenged by Singh as a violation of his Section 7 Charter right to life, liberty and security except in accordance with the principles of fundamental justice as a hearing should be needed to satisfy the principles of fundamental justice. However, the prosecution argued that Singh was not a Canadian citizen or a landed immigrant and therefore, could not avail himself of Canadian Charter rights. Nonetheless, the Supreme Court established that the term "everyone" in the Canadian Charter of Rights and Freedoms applies to all those present in Canadian jurisdiction (Singh v. Minister of Employment and Immigration, 1985).

Therefore, the findings of the Supreme Court imply that the following sections of the Charter apply to asylum seekers just as much as they do to Canadian citizens: Section 7: the right to life liberty and security of the person and the right not to be deprived thereof except in accordance with the principles of fundamental justice; Section 9, protection against arbitrary detainment and imprisonment, and; Sections 10 a) informed promptly of detainment reasons b) retain and instruct right to counsel without delay and to be informed of that right, and c) validity of detention determined by way of habeas corpus (before a judge in court).

With this in mind, it is clear that migrants are granted three types of rights: rights provided to them under the IRPA, rights in the country provided under the Canadian Charter of Rights and Freedoms, and 'basic human rights' provided under the United Nation's Universal Declaration of Human Rights (UDHR) that Canada ratified. Some of these basic human rights include but are not limited to, "the right to security of one's person and property, the right to lifesaving medical treatment, and basic freedoms such as freedom of religion and freedom of speech". Article 25 of the UDHR also grants everyone "the right to a standard of living adequate for the health and wellbeing for himself and of his family, including food [...and] necessary social services..." (UN 
General Assembly, 1948). These rights, in theory, should be provided to any human being, simply for being human, regardless of their legal status.

It is important to understand Canada's commitments to refugees and the rights provided to them through international agreements. There is a clear comparison between rights that are promised and rights that are actually respected. The mismatch is mapped out in the next few sections which outline the creation and distribution of the "fear of migrants" and the ways in which detention centres act as prisons. The conditions blatantly depict the role of Canadian policymakers in violating the promised rights with little regard, in the name of national security. This rationale is further solidified by of Canadians' tolerance of the human rights' violations migrants endure.

\subsection{Political \& Media Discourses: The Exaggerated "Fear" \& Moral Panics}

In analyzing the political and ideological discourses surrounding the criminalization of migration, it is vital to analyze the events that fueled the desire to increase the securitization of borders. The terrorist attack of September 11, 2001 and the subsequent attacks in London and Madrid are widely accepted as the breaking points on the already existing security measures in place to limit immigration (Bigo, 2002; Stumpf, 2006; Karyotis, 2011). Still, it is important to note that the links between migrants and threat predate September 11. For example, Amin-Khan (2015) argues that migration was coupled with national security concerns in the USA, once the Immigration Reform and Control Act (IRCA) was passed in 1986 by the Reagan government in order to tighten border controls and increase border enforcement, highlighting the desires to determine acceptable members of society. In 1994, the Clinton administration aimed to control "illegal" immigrants from Mexico by authorizing a fifty billion-dollar, fourteen-mile security fence to be built along the southern border (p. 26). This was followed by several Acts which aimed 
to restrict access to government services for migrants, further securitize borders, criminalize assistance to undocumented migrants, and build more fencing at the US-Mexican border.

There is no doubt that Canada's security laws often mirror those of the United States, at least in part by discussions in the United States because of the Canadian exposure to American media. Canada had its own laws in place which strengthened the narrative deeming migrants as criminals. A significant Bill passed in Canada was Bill C-44 passed in 1995 which removed a person's right to appeal a removal order if the Minister of Citizenship and Immigration deemed that person a danger to society (Amin-Khan, 2015). Therefore, once the Immigration and Refugee Protection Act (IRPA) was enacted in 2002, it "reinforced the oppressive use of security certificates, and expanded the inadmissibility categories to permit refusal of entry on the grounds of security" (Amin-Khan, 2015, p.127).

Canadian policy, and its divergence from Canada's legal responsibilities towards refugees was shaped by a series of moral panics. The concept of moral panics implies that an occurrence which is perceived as a threat to society "has the potential to critically change social values, norms, and regulations and that its occasion may vitally disrupt the sanctity of society" (Hauptman, 2013, p.3). An enormous amount of passionate and emotional political and news coverage of an incident or phenomenon results in the formation of an exaggerated fear and threat (Hauptman, 2013). Moral panics then create changes in both formal social control mechanisms such as government policies but also in informal social control mechanisms which include all other social influences, such as the media. In so, Cohen (1972) argues that there is a binary formed; Moral Guardians as those who swoop in (often politicians) to "fix" the moral problem, and the Folk Devils, who are constructed as a threat to social order. In this case, immigrants are viewed as the folk devils that threaten the nation's peace by being a "burden" on the system. Meanwhile, politicians and those 
in power are the moral guardians who aim to "fix" this problem by implementing laws to deter and regulate immigrants.

For instance, Ibrahim (2005) looks at the anxiety the Canadian government, press and public experienced at the arrival of 599 Chinese 'Boat People' in 1999 who were portrayed as disease carrying threats to human security. Public actors continued to link the migrants with words like illegal, criminal, and illegitimate. Multiple news outlets depicted their arrival as a threat—of increased crime, to public health, and even as foreshadowing the collapse of a welfare state because resources and government funds would need to be provided to them (p.174). Karyotis (2011) argues that once a certain realist policy frame, such as 'migrants are dangerous criminals', is prominent, it is determined to be the 'correct' way to define an issue. This is evident when considering the fact that Ibrahim's literature review of the Chinese 'Boat People' of 1999 shows they were criminalized by the press. This framework then solidifies the need for the securitization of migration because the migration of racialized people is consistently transformed into a "crisis" that needs to be solved by politicians (Ibrahim, 2005 p.174). The media passionately covered the story and created the moral panic in which the Chinese 'Boat People' were folk devils and so aimed to provoke the government to do its part as the "moral guardians" and protect society from them.

Thus, the securitization of borders is both an outcome and a reaffirmation of hegemonic discourses that link risk and threat to racialized migrants. Ibrahim (2005) argues, "in uncovering how migration has become a security issue, it is instructive to highlight how "cultural difference", as a system of classification, is associated with threat. This use of "cultural difference" as a criterion for exclusion can be understood as a racist discourse (p.165). The post-9/11 environment produced the War on Terror, targeting migrants coming to Canada and the USA from Muslim 
countries (Amin-Khan, 2015; Fekete, 2004; Karyotis, 2011; Toğral, 2011) and fueled the securitymigration nexus. The terrorist attacks allowed a system of racial profiling by non-racialized people to occur, creating an increased concentration on 'enemy aliens', especially from Muslim-majority countries, and profiling all Muslims, citizen or not, as terrorists or criminal threats even across Europe (Fekete, 2004).

Fekete (2004) provides an example when she highlights the "trial by media" that Muslims experienced post 9-11. The media substitutes the court and the press becomes "not only the arena where the suspect is tried, but the judge and jury, too" (p. 14). She gives multiple examples of the ways in which arrested Muslims in Europe were assumed to be linked to Jihadi or al Qaeda groups in the press, even before trial or conviction. The enormous amount of passionate coverage of 9-11 led to Muslim men in general to be viewed as the 'Folk Devils' that society should fear around the globe. For instance, in one case, twenty-eight impoverished Pakistani street vendors were arrested in Naples in early 2003. Though the men were barely scraping together a living, they were arrested on "suspicion of association with the aim of international terrorism, possession of illegal explosive material, falsification of documents, and trafficking" (p.15). The Naples media responded by reporting the uncovering of an 'al-Qaeda terrorist cell' while citing an anonymous police source who claimed that there was a plot to assassinate Britain's Secretary of State for Defence, attack the US consulate and nearby tourist spots. The media continued to report that the number of explosives seized could have blown up a ten-story building. Two weeks after the arrests of the men, all were released as there was "no evidence that the defendants were linked to al-Qaida and they had not been aware of the explosives in the flat" (p. 15). Fekete (2004) discusses several other cases where Muslim migrants were depicted as criminals in the eyes of the public by both informal and formal social control mechanisms. In this way, the press plays a huge role in the criminalizing 
of racialized migrants by creating a moral panic that provides the public with assumptions rather than factual news.

In attempts to fix the 'crisis' of the moral panic following the September 11 attacks, the Harper government, which came into power in 2006, introduced multiple policies stemming from cultural difference; they were able to exploit fears of both homegrown and external terrorism by Muslims in the West. One development included the "Zero Tolerance for Barbaric Cultural Practices Act" making it illegal to engage in polygamy, child marriages, and honour killings—all acts that were already prohibited under the Canadian Criminal Code (Zhou, 2014). Obviously, no government will openly acknowledge racist policies, but it is no surprise that the consequences of policies implemented in the name of border security and anti-terrorism targeted and criminalized racialized migrants (Amin-Khan, 2015) using methods of new racism (Toğral, 2011). The polices benefited the self-interests of the elites that promoted them (Bigo, 2002; Karyotis, 2011) while creating deeper fears of migrants in the eyes of the public. Leaders that introduced the policies were painted as effective leaders who cared about national security and the state of the nation.

In addition to the "Zero Tolerance" policy, the arrival of a boatful of Tamil asylum seekers in 2009 yet again provided the Harper government with an excuse to criminalize immigration in the name of security and argued that a deterrence message should be sent to smugglers, similar to that of the Chinese 'Boat People' in 1999. Bill C-31, Protecting Canada's Immigration System Act, introduced many restrictive measures including excessive security screening which, unsurprisingly, continued to target racialized migrants. According to Amin-Khan (2015), Bill C31 even treated visitors on valid visas from certain Muslim-majority countries as national security risks, requiring them to undergo excessive security screenings which are likely held in a permanent database (p.130). 
This political discourse was used to satisfy the dominant narrative in society that the government was doing its job, preventing abuse of the system and keeping Canada safe. For instance, the Immigration and Multiculturalism Minister in 2010 even stated, "Canada's asylum system is broken...we must act to avoid a two-tier immigration system: one for immigrants who wait in line... and another for those who use the asylum system...to try to get through the back door into Canada" (Social Development Canada, 2010). Bigo (2002) argues that "speech acts" justify both the normative position of the speaker (often state actors) and the value of their critical discourse (p.65). Therefore, the rhetoric of this "speech act" by the Immigration and Multiculturalism Minister reinforced the principles of membership theory as it defined the difference between a "good" and "bad" migrant, while subtly implying that criminal sanctions for such actions are justified. Still, the research shows that these methods were not successful in deterring migrants and asylum seekers and instead, simply made it more difficult for migrants to come in, (Amin-Khan, 2015; Ibrahim, 2005), as well as making them more vulnerable to injustices and human rights violations. In any case, the creation and reinforcement of the 'fear of the migrant' framework by political parties allows them to create policies that justify their legitimacy.

\subsection{Detainment Centres as Prisons}

The existing literature on immigration detention centres focuses primarily on the demographic of people held within them, the length of their detention, and the conditions of the facilities. Implementations made to the Immigration and Refugee Protection Act (IRPA) in 2002 fundamentally removed certain rights for migrants, allowing a person to be charged, without being entitled to know why and on what grounds. Canada has followed in the footsteps of other nations by permitting the indeterminate detainment of migrants without due process under IRPA (Chairperson's Guideline 2, 2010). This is then a criminal sanction used to punish migrants for 
immigration violations emphasizing the merger of immigration law and criminal law. Amin-Khan (2015) quotes Public Safety Canada (n.d), "The security certificate process within the IRPA is not a criminal proceeding, but rather an immigration proceeding" (p.128). He further emphasizes this contradiction when he says, “... select criminal laws have been integrated into IRPA with a diminishing need to rely on the Criminal Code for criminal convictions" (p.128). This can be linked to the concept of Crimmigration (Stumpf, 2006).

According to Menjivar (2014), noncitizens may be detained if they are not clearly entitled for entry, are awaiting removal proceedings, or have an order of removal. They therefore suffer the same punishment (detention) as criminals except for the fact that migrant detention is indefinite unlike that of a convicted offender. The onus also rests on the migrant to prove that they are harmless. In other words, migrants are considered guilty until proven innocent, unlike accused criminals who must be considered innocent until proven guilty beyond a reasonable doubt—yet, the sanctions and limitations to freedom of movement are the same. In addition, criminals are detained only after they are found guilty or await their trial; meanwhile migrants are detained while waiting to hear from the government about their status and presumed to partake in criminal conduct, threatening the nation.

The criminal sanctions being imposed to enforce immigration law equate a serious criminal offence with violating immigration law. Detainment laws work to regulate and enforce national borders internally through the policing of noncitizens who are presumed to engage in future criminal or threatening behaviours. This is partly possible due to the growing public tolerance for the "infringement of immigrants' rights, indefinite detention, and even racial profiling" (Menjivar 2014, p.356). The criminalization of migrants also invokes a tautological rationale, arguing that 
migrants may be criminals, and thus need to be detained or that migrants must be criminals, because they are detained (Mountz, Coddington, Catania, \& Loyd, 2012).

Those in immigration detention suffer the criminal sanction of detainment for an immigration issue, but do not receive the criminal due process. This ties into Stumpf's (2006) theory on the crimmigration process in which criminal law and immigration law overlap and are used to exclude immigrants from feeling like members of their society. For example, in immigration detainment, there is no right to legal aid, legal counsel, and there is little judicial oversight. In fact, before Chaudhary v. Canada, one had to apply and be granted leave before they would even receive judicial review regarding their detention; the entire process could take up to four months. However, since the case, it has been agreed that detention cases can be heard in the provincial courts under violations of Habeas Corpus-something guaranteed to everyone in Canada. So, it is determined that since the criminal sanction is used, Habeas Corpus, the criminal protection, should be available in immigration cases (Chaudhary v. Canada, 2015). This alone shows that immigration detention does in fact criminalize immigrants.

When looking at the actual conditions of detainment, public officials insist that migrants are held in hotel-like conditions. With the passing of Bill C-31, the Minister of Citizenship and Immigration insisted that immigration "holding" centres are not jails, they offer good living conditions (Dawson, 2014) and provide safety and security for the receiving country's citizens. Meanwhile, according to an article referenced by Dawson (2014), immigration detention centres are run as medium-security prisons, complete with fences topped with razor wires, centrally controlled locked doors, security guards, and surveillance cameras. Furthermore, men and women are held separately with a special ward for children detained with their mothers. There are regular searches, including body searches, confiscation of personal effects and no activities other than a 
television in some wings. There are strict wake-up times, mealtimes, and even instances of solitary confinement (Mountz et al., 2012). Many irregular migrants in detention have spoken about regular lockdowns, neglect or verbal abuse from guards, and lack of health care (Cole, 2016). Cleveland and Rousseau (2014) describe conditions of detainment:

Detainees are deprived of liberty and agency, not only by confinement but also through control over minute details, such as taking a daytime nap. Length of detention is unpredictable and contact with families difficult. Detainees have little to do except think about their problems, worry about being deported, and about the well-being of their family back home, and experience extreme boredom that reflects loss of agency (p.414).

There are also many reported instances of migrant deaths under the custody of the CBSA, yet they refuse to reveal the migrants' names, age, countries of origin, and circumstances of death. Cole (2016) states that the authoritative body "insists on erasing the humanity of the migrants they detain, even in death" (para.1). Clearly, the detainee's "right to security of the person" under the UDHR is not just violated but ignored altogether. Unsurprisingly, there remains a disproportionate number of blacks and browns in detainment; their legal status is used as a tool to instill 'new racism' (Toğral, 2011). Instead of a shelter or a place where migrants are treated with dignity and respect as they await a decision, they are confined, hypersurveilled, and hypercriminalized (Menjivar, 2014). The migrants' identity is reduced simply to their legal status and humanity is ignored.

The long-term effects of detainment on migrants and asylum seekers are neglected by policymakers and enforcers. Undoubtably, migrants who are fleeing persecution or war, leaving their homes and families, and travelling with the uncertainty of survival likely experience mental stress, fatigue, and even symptoms of post-traumatic stress disorder (PTSD) and depression. 
Indefinite inhumane detainment exacerbates these mental health issues, causing an even more difficult journey to recovery and integration. Cleveland and Rousseau (2013) examine the association between detention and psychiatric symptom levels among adult asylum seekers in Canada. They use multiple questionnaires and checklists to assess psychiatric symptoms and premigration trauma in 122 detained and 66 non-detained asylum seekers in Montreal and Toronto. They concluded that when comparing the mental health of detained and non-detained asylum seekers, PTSD, depression, and anxiety levels were found to be significantly higher in the detained group after an average of 31 days (p.413). It is also important to note that there were no significant differences in pre-migration trauma exposure between the two groups.

This alludes to the serious consequences that detainment has on the mental health of adults — let alone of migrant children — who are detained for indefinite periods of time, with little to no explanations of why exactly they are detained or for how long (Menjivar, 2014). These types of mental stressors threaten social cohesion within migrant groups which then could lead to difficulty integrating and future criminality (Fekete, 2004; Mountz et al., 2012). In this sense, it is important to consider the ways in which the criminalization and detention of migrants may in fact be setting them up for the worst. Without the proper avenues to heal from or even cope with their traumas, asylum seekers are left even more vulnerable than they once were.

Migrants of all ages continue to be criminalized and the CBSA and Canadian government lack transparency. The human rights' violations in detention centres are hidden and there is no true accountability. Regular and irregular migrants should be given their inalienable and ratified rights in order to prevent further injustices. Yet the criminalization of migrants, even in detainment centres has a domino affect on their mental health. Cleveland \& Rousseau (2013) recount detainee experiences when they report, "almost all detainees described feelings of shock and humiliation 
when handcuffed, and most felt that they were unjustly treated like criminals. Many detainees postponed medical treatment rather than submit to the shame of being publicly handcuffed in a hospital waiting room, with the attendant risk of aggravation of their health problems" (p.415).

In addition, Dawson (2014) credits the mismatch between "official" descriptions of detention centres with their reality to the desire for Canada to be viewed as hospitable and generous. In fact, she argues that this is why many officials refuse to acknowledge the placement of detained migrants in provincial prisons. In reality, many migrants, especially those who exhibit behavioural or mental health problems are detained for longer periods of time, have reduced access to lawyers, and are frequently held with and not distinguished from the rest of the prison population (p.829). As a matter of fact, use of provincial prisons for immigration detention has increased dramatically between the years 2009 and 2014, accounting for one-third of all detainees in 2011$2012(\mathrm{p} .829)$.

The responsibility to protect refugees is ignored. It is forgotten by both policymakers and Canadians that many irregular migrants are seeking asylum in order to escape persecution and the fundamental rights to life and liberty, as well as adequate health care are ignored. Canada claims to care about these people yet migrants continue to be treated as criminal aliens undergoing abuse, degradation, and death due to the conditions of detainment and the difficulties of immigration law. Migrant rights are ignored in the name of security (Menjivar, 2014) and other social and political goals. Fundamental human rights provided under IRPA, the Canadian Charter of Rights and Freedoms, and the UDHR are constantly denied for migrants in detention, many of whom have no prior criminal records. This can be credited to political and ideological discourses, with the aid of the press, whom create and reinforce the rhetoric that racialized migrants are criminals. This then results in the creation of a hostile environment for people of colour, even if they are legal citizens. 
Nonetheless, there are multiple solutions offered to help minimize the human rights' violations of migrants. Legislation to improve Canada's asylum system are discussed by the Auditor General of Canada in a 2010 news release. He argues that balanced reforms would increase support for refugees in need of protection and discourage unfounded asylum claims. This way, faster and more efficient protection would be delivered to those in need. Proposed measures would shorten the average claims heard process from nineteen months to sixty days (Social Development Canada 2010, par.5). Asylum seekers would also be able to access a new appeal process at the Immigration and Refugee Board of Canada, allowing them, in certain cases, to present new evidence (Social Development Canada, 2010). Improvements to the asylum system would benefit taxpayers too, as the cost would be reduced from $\$ 50,000$ to $\$ 29,000$ per claim. More funding would be provided to Resettlement Assistance programs, aiding in integration for migrants. This is especially important because even brief detention, under conditions less harsh than many other countries, is associated with psychiatric symptoms. Temporary placement in a supervised residential facility may be a more effective alternative to detention (Cleveland \& Rousseau, 2013). Mountz et al. (2012) discuss the need to question the association between coercive confinement and safety and security. They argue that whose security is at stake is perhaps better understood by examining the perspective of those people attempting to seek safety and opportunity in the face of persecution, humiliation and exclusion.

\section{Content Analysis}

\subsection{Methodology}

In order to examine the ways in which media outlets examine detention centres and create links between the role of the media in creating the hegemonic Canadian discourse, a content analysis will be employed. It will be used to reveal messages that are communicated to the 
Canadian public about these issues and describe attitudinal and tonal messages in the media. This method will be used to identify major reoccurring themes, concepts and topics covered in Canadian media. Therefore, the findings will be divided into the recurring thematic categories of the coverage that is examined. The analysis aims to strengthen and justify the literature review's findings, assessing whether detention centres are, or are reported, as sites of criminalization and human rights violations. This method is more effective than other methods such as interviewing and observation for multiple reasons. First, due to the time constraints of this research, pursuing ethical approvals for a short analysis of detention centres would be time-consuming with little benefit. There would also likely be multiple barriers in recruiting and speaking to detainees to gain knowledge about the ways in which detention centres operate. Furthermore, observational research would require visiting detention centres, however, it is impossible to gain valuable information about the conditions of detention centres from a brief visit. This is because a lot of what happens in these centres occurs behind the scenes and in secret.

Journalists and the media often aim to cover up information that is controversial or requires exposure to the public. Given that this section of the paper aims to examine the media's role in disseminating information about detention centres, the best resource is to look at the media directly. Some research questions this content analysis aims to explore are: How are detention centres discussed in the media? Is the information being provided factual, emotional, in favour or condemning of these spaces? Do articles discuss the conditions of the spaces and shed some light on some of the reasons one may be detained? Why do Canadians tolerate this situation? What role does the media play in this?

The content analysis will cover twelve media coverage pieces that discuss Canadian detention centres. The media will be found on the internet on Google, Google News, RULA 
Database, and other online mediums. This search strategy includes searching by keywords such as: 'immigration detention centres \& Canada' and 'migrant holding centres \& Canada'. Media can include both factual newspapers (online) and opinion pieces. Finally, the content analysis will examine media from the past two years. Though more recent articles were sought, the coverage on detention centres in Canada remains limited.

\subsection{Findings \& Thematic Analysis}

The findings of the content analysis are divided in the following four major recurring themes: "How They Work", "Public Opposition", "Not as Bad as the U.S." and "Prison-like Conditions". Although not all twelve articles are mentioned by name or author in the below sections, it is important to note that each of the twelve articles examined contains one or more of the four major identified themes. For a complete list of all the analyzed articles in this section, please refer to Section 6: Media Articles of this project.

\section{i. "How They Work"}

Some of the media articles take the initiative to try and educate the Canadian public about how detention centres in Canada actually function. This is important because this information sheds light on the policies and procedures of the immigration centres that very clearly exist in our society. Most articles begin by discussing the size of the facilities and their capacity and is often followed by the CBSA's colourful and appealing description of the facilities. For instance, "How Immigration Detention Centres Work in Canada" (Bensadoun, 2019) notes that the CBSA says there is separate accommodation for men, women and families, daily meals, access to games, televisions, phones, medical services and visitation areas. According to the CBSA, "everyone in its holding centres get three meals and two snacks per day, and special dietary needs, such as food 
allergies or specialized diets, are catered to" (par.6). Essentially, immigration detention centres are described like hotels by the CBSA, and this is the first description provided in the articles. Though all the articles that state this later continue to describe the ways in which the conditions are the complete opposite of the CBSA's portrayal. However, it is unclear how closely people read these articles and whether they even realize that the CBSA's portrayal of the centres is not the actuality.

The CBSA also argues that provincial correctional facilities are only used to hold higherrisk detainees such as those with a violent background and low-risk detainees whom are in areas that do not have a detention centre (Bensadoun 2019; CityNews, 2019) Interestingly, of the twelve articles examined, three describe the CBSA's detention centres as located in Toronto, Laval, and Vancouver. Some other articles mention this; however, it is later in the respective articles. With the lack of information about the location of the detention centres in other articles, it is possible that readers may not view this problem as prominent; there is little information telling them where it is happening, possibly resulting in a "not in my backyard, not my problem" type of attitude.

One of the major red flags in the articles examined includes the little information provided about why one may be detained, for how long, if it can be appealed, and other procedural matters. Bensadoun's "How Immigration Detention Centres in Canada Work" (2019) was the only article to discuss length of detention, albeit only briefly. The article informs readers that, "detainees have their cases reviewed at certain intervals -- the first within forty-eight hours of detention, again after seven days, and then every thirty days until their detention is resolved" (par.9). This is followed up with the clarification that detention is indefinite and there is no limit on how long a person can be held. The only way a case can really be resolved is "through release into the community, usually on conditions, or through deportation" (par.10). The indefinite detention periods are also briefly mentioned in "Canada Needs to Get Out of The Detention Business", comparing the lack of 
knowledge detained migrants have about their release-something even convicted murderers are aware of when behind bars. Furthermore, the article fleetingly mentions that the CBSA's official stance towards immigration detention centres includes using them only as a last resort in situations where, for example, examination needs to be completed, there are security concerns, grounds to believe than the individual will not appear for an immigration proceeding, or the government is unable to identify the individual due to lack of papers.

Interestingly, almost eight of the twelve articles admit that there is an intentional secrecy surrounding the immigration detention system. They argue that the lack of transparency, along with the lack of independent national and international oversight bodies significantly "contribute to the culture of secrecy" (Keung, 2018, par.2). In fact, this secrecy leads directly to the lack of information published and public knowledge about the ways Canadian detention procedures works. Unfortunately, even articles that specifically aim to shed knowledge such as "How Immigration Detention Centres Work" (Bensadoun, 2019) and "Canadian Immigration Detention Explained" (CityNews, 2019) are unable to provide more than just generic information about detention centres to Canadians.

\section{ii. "Public Opposition"}

An important recurring theme of the articles was that of consistent public opposition against detention centres. Five of the twelve articles retrieved and examined discuss the different ways in which members of society are standing up against detention centres and the conditions within them. Much of the public protest however, remained in Laval, Quebec, where a new detention centre is planned to be built and operational by 2021. "Fifty Groups Unite to Speak Out Against New Refugee Detention Centre in Laval" (CTV Montreal, 2019), "This Is A Prison, No Matter What You Call It" (Milton, 2019), and "Activists Step Up Protests of Planned Laval Detention 
Centre for Migrants" (Magder, 2019) look specifically at the public action in Laval, against the construction of a new detention centre. It is important to note that the titles of the articles on their own use language that facilitate public disapproval and even hostility towards the centres. They draw the attention of the public, provoking readers to read on and learn about the conditions of the centres.

The articles detail how protestors feel about different aspects of detention. For instance, many protestors discuss the horrifying situations that children endure in immigration detention centres, arguing that this this should be a legitimate reason for public outrage (CBC Radio, 2019; Milton, 2019). Others are baffled at the similarities between immigration detention centres and prisons, arguing that Canada should be doing more to welcome refugees, especially given that many risked their lives to escape their previous living conditions and thus, likely have PTSD, depression and other mental health issues. The articles also detail the actual opposition efforts made by protestors. For example, “This Is A Prison, No Matter What You Call It” (Milton, 2019) discusses how a group that called themselves the "ani-construction crew" in Laval ripped a sheet of plywood off the wall of the building which housed the head offices of Lemay, a company involved in building the detention centre. They then let loose thousands of crickets into the space. Other group members smashed windows, glued the locks shut, and destroyed the electronic sensors of other buildings designed by Lemay. The group also broke into Lemay's head office in broad daylight with masks and threw paint bombs and broke most ground-level windows. The article continues to discuss several other incidents of protests against companies involved in the construction of the detention centre because of the negative impact they have on migrants.

The actual content of the articles that discuss public opposition of course aim to report the news but the message is important to relay to readers because it can create a public dialogue and 
perhaps bring Canadians together against migration detention centres once readers understand the reasons behind protests and petitions. It is also a vital way to encourage Canadians to band together and believe that they actually can bring about change and their efforts have a meaningful impact. In fact, an activist even reported that he heard that one company responded to the attacks requesting for protestors to 'please stop calling us, we're no longer bidding for the contract' (Milton, 2019, par.42). In this way, the articles use themes of public protest and employ harsh, emotional language towards the migration detention centres in attempts to shape the general public opinion about detention centres, while also hoping to gain further public support towards their cause.

\section{iii. "Not as Bad as the U.S."}

Canadians have the tendency of comparing themselves to the Unites States, often attempting to depict Canada as a more peaceful and accepting country. Perhaps this is due to the smaller population, the official multicultural mandate in Canadian federal policy, and people's personal experiences. In any case, Canada's mistreatment of migrants, especially in detention centres seems to be trivialized by Canadian politicians, and often, the media too. In fact, Amy Darwish, a spokesperson for the group Solidarity Against Borders literally feels that "[..] people don't know that these things [mistreatment of migrants in detention centres] happen here, too." (Magder, 2019, par.2). This may be the case because Canadians are more likely to see media discussing American detention centres compared to Canadian ones, resulting in a confirmation bias that Canadians are in fact nicer and more accepting than their neighbours to the South.

Interestingly, when "detention centres" is searched in Google News at the time of publication of this project, of the ten articles that show up on the first results page, seven cover American detention centres, one covers a Libyan detention centre and the remaining two are about Canadian detention centres. Similarly, as mentioned in the methods section of this analysis, finding 
up-to-date, nonpartisan coverage of Canadian detention centres was a lot more difficult as search results flooded with U.S news. This is two-fold as a lot of what happens in these centres is purposefully kept out of the public eye and thus, there is less coverage of it in the media-further keeping it out of public minds (Keung, 2018; Molnar \& Silverman, 2018). Therefore, the overall lack of coverage on Canadian detention centres may be an explanation as to why the "Not as Bad as The U.S.” theme is prevalent in the articles that $d o$ discuss Canadian centres.

In "How Canada Reduced the Number of Children Held in Immigration Detention", Browne (2019) discusses the ways in which Canada's response to addressing minors in detention centres should be mirrored by the United States. In other words, this article proposes that Canada's detention centres are if not perfect, close to it and thus, should be used as a guideline for other nations, such as the United States to follow. The article starts off by slamming the United States' treatment of children in detention centres by quoting Rachel Kronick, a professor at McGill University who says,

The U.S. is setting kids up for physical and mental health problems and an inability to integrate...They're creating such demeaning, dehumanizing and cruel conditions for children and families that they are breaking down the social fabric not just of these communities of migrants but of the United States itself (par.6).

Words such as "demeaning" and "dehumanizing" used to describe the United States' policies aid in painting a portrait that depicts the U.S. centres as horrid. This is especially the case when in contrast, Canada's immigration detention regime is being highlighted as improving. For example, the article capitalizes on the statistic that from 2014-15 to 2018-19, there was a 51\% drop in minors held in detention centres. Though this is a meaningful statistic, it simply is impossible to learn meaningful information about Canadian detention centres and the human rights violations that 
occur within them. Furthermore, CBC Radio (2019) and Keung (2018) outline the phenomenon of "invisibly detained children" which describes that children are effectively being separated from their parents and thus are not recorded as detainees themselves because they are not literally in the detention centre. Therefore, the children are "invisibly detained" because they are not present in statistics. In addition, the separation of children from their parents, after already witnessing traumatic events, may result in the need for years of psychological support to address anxiety, depression, behavioural issues, etc. Obviously, this process results in longer re-integration for the children. In this way, it can be seen that the superficial argument that United States is worse off because Canada detains fewer minors is extremely flawed.

Still, some media sources use the excessive coverage and discussion of American detention centres as a way to start the conversation about Canada's centres. For instance, Magder (2019) points out that "with the detention of migrants making headlines south of the border, activists say more light needs to be shed on the mistreatment of migrants in Canada" (par.1). In another article by Molnar and Silverman (2018), the authors argue that Canada only really began to self-reflect after "we [Canadians] started learning of the horrors of immigration detention in the U.S" (par.2). The language used highlights the need to share information about Canada's detention policies and conditions, while also perhaps calling for readers of the articles to look inward and ask themselves what they really know about Canadian detention centres. Interestingly, while building this research and reaching out to members of society who are not in the academic fields of humanities or social sciences, the reactions I received when explaining my research included comments along the lines of "we have those [detention centres] here? I thought those were only in the United States". So, the rhetoric that detention centres are a "U.S problem" and that Canada probably does not have 
this issue because Canada is "not as bad as the U.S" depicts an information gap for the public (Keung, 2018).

iv. "Prison-like Conditions"

Several articles outright call out detention centres for having prison-like conditions, while other use terminology to highlight this phenomenon more subtly. In any case, migrants are denied rights protected under both IRPA and the UDHR. In fact, more and more attention is being drawn to the fact that many migrants are actually being held in provincial jails. Enforcement officers are soon to be required to wear steel-toed boots, soft body armour, a defensive baton, pepper spray and handcuffs (Wright, 2019). "Concerns Mount Over 'Criminalization' of Detained Migrants in Canada" notes that some of these tools are the same as correctional officers in maximum-security prisons and thus, immigration detention centres will have an environment akin to jail conditions. This approach then implies that migrants, including children, are dangerous criminals worthy of punishment. The article quotes Anthony Navaneelan, a lawyer who works with Legal Aid Ontario who says,

The idea of getting them out of jails is to recognize the fact that it can re-traumatize refugee claimants to be putting them in detention to begin with when they've committed no crime... Also in terms of necessity, CBSA hasn't identified for us any incidents that have happened at the immigration holding centres that would warrant these types of measures. ...we certainly think escalating or creating an environment where officers are equipped with these types of measures is almost a solution in search of a problem (par. 16)

The article aims to depict the viewpoint of several professionals in the field whom are opposed to the prison-like environment and behaviour of the enforcement officers. In this way, readers can appeal to authority and use the authority's arguments against the detention centres conditions as 
legitimate. In addition, the appeal to authority may provoke readers to learn some information about detention centres themselves so they can formulate their own, educated stance on the matter. In so, the articles condemn detention centres and use persons of authority to aid them.

The article titled "This is a Prison, No Matter What You Call It" (Milton, 2019) discusses the many inhumane conditions of detainment, calling into question the accountability of the CBSA and the Canadian government. A migrant girl who was detained for just over a week at age sixteen described some of the prison-like conditions in the article. For instance, she points out that the windows were too little to even be able to see outside, the doors were always locked, and the beds were so uncomfortable that it felt like sleeping on the floor. She continues to say that the detainees were not given covers in the cold cells and were awaken at 3:45am to eat two- or three-day old food. She points out that sometimes they would not eat it, but sometimes they were too hungry to have a choice. She said, "they treated us like we weren't human beings, like we were animals" (Milton, 2019, par. 13). The article goes on to discuss the Immigration and Public Safety Minister, Ralph Goodale's lack of attention given to a hunger strike organized by detainees in two maximum security prisons in 2016 in Ontario to protest against the conditions of their confinement. The detainees simply wanted to meet with Goodale who announced he would "overhaul Canada's migration detention policy" (par. 16), and never met with the hunger strikers.

The structural design and procedures within detention centres is discussed in several articles that aim to paint a picture of the inhumane conditions of detention centres. Articles discuss how the building is presented as warm and welcoming on the outside with low-voltage lighting, wood sourced from Forest Stewardship Council-certified forests, and recycled material in the facility (Wright, 2019). However, the rooms “"must eliminate protruding objects that could heighten the risk of suicide by hanging [and] ensure maximum surveillance of detainees.' All the 
windows facing outside will be covered in iron bars, which 'must be designed in a manner that makes them as inconspicuous as possible to the outside public."' (par. 28). The yard is to include fencing that is minimum eight-meters high, complete with barbed wire on the top. It is important that articles shed light on the conditions of detention because the secrecy surrounding the procedures can then be challenged and spread to other Canadians.

The issue of indefinite detention periods is also widely discussed in media articles as briefly discussed in "How They Work". No one, not even the CBSA agents really know when a detainee will be released or to where. The discussion of human rights is important in condemning detention centres because "migrants end up in detention centres and jails, for indefinite periods of time, because they are not Canadian citizens and are therefore deemed to have no rights" (Cole, 2016, para. 2). Migrants of course, do have rights whether or not they are Canadian citizens as discussed earlier under multiple provisions such as the Canadian Charter of Rights and Freedoms (applied to migrants under Singh v. Minister of Employment and Immigration), and the UDHR. "Supreme Court Says Migrants Can Bring Detention Challenge to Judge" (Harris, 2019) even reports that the Supreme Court of Canada has ruled that refugee claimants have the right to challenge their prolonged incarceration because it violates the charter rights to liberty and freedom from arbitrary detainment. The article continues to detail the reasons for this ruling, as the principle of habeas corpus allows someone in custody to go before a judge to challenge detention, setting aside the exception that migrants without Canadian citizenship could only challenge their immigration detention through immigration tribunals or federal judicial view.

The importance of media articles of this nature is vast because readers can learn about and understand the severity of immigration detention when the procedures are being compared to those of criminal law. In this way, Canadians are prompted to think about the extreme measures being 
taken towards innocent migrants who are claiming asylum and perhaps act on moral and emotional grounds to protest and fight against the criminal sanctions. The United Nations condemned Canada's practice of detention and recommended that Canada adopt a ninety-day limit. The conditions in detention do not seem like "a safe haven for migrants" as IRPA aims and deny basic human rights such as a living standard, adequate food, health services and well-being as per the UDHR (Menjivar, 2014).

\section{Conclusion}

\subsection{Conclusion: Next Steps}

Research continues to confirm that Canada's immigration detention is unjustly punitive. Canadian and United States law confirms that claiming asylum is a human right and completely legal at a point of entry. However, immigration detention centres continue to penalize bordercrossers and cause negative long-lasting psychological and social impacts on migrants. Therefore, proposed policy changes such as Alternatives to Detention (ATD) programs aim to reduce the harmful impacts of migrant detention. They include non-custodial, community-based monitoring of those immigrants who would have otherwise been detained. An example of an ATD program is the Community Assessment and Placement (CAP) Model (IDC Coalition, 2018). This model assumes liberty for migrants and gives them access to minimum standards of rights such as legal review, legal counsel, and legal aid. The detention of vulnerable individuals, such as those with mental health issues would be prohibited. There would also be regular screening and ongoing case assessment, and based on this, those waiting deportation/travel documents, etc., would be put into the community under three different "security" levels. The first would be in the community without conditions, the second would be in the community with conditions, and the last resort would be in detainment with review. Constant case management and support would be provided to ensure that 
the human rights of migrants are not violated. This way, there is consistent accountability and support for the migrants in question.

ATD programs have been shown to be effective at achieving migration objectives without human rights violations. IDC (2018) finds that ATD programs have been shown to "maintain high compliance rates with a range of migrant populations, in particular when migrants are able to meet their basic needs, and are able to access the legal and social support necessary to make informed decisions about their migration journey" (par.4). Furthermore, it is found that ATD programs are significantly more cost-effective than detention. This is because less money would be spent on detaining migrants and building more detention centres. At the same time, cases would be managed in a community setting, reducing procedural and medicinal costs. Finally, ATD programs respect human rights as there is a reduction on the reliance of unlawful or arbitrary detainment (IDC, 2018). Plus, migrant well-being and pre-migration trauma could be addressed, while keeping families together and avoiding further distress.

Even in current cases of detention, human rights-based approaches could include funding to be allocated to expedite proceedings, ensure legal counsel or lawyers are present at proceedings, and catering to the mental health of asylum seekers experiencing mental health issues. Molnar \& Silverman (2018) suggest telephone or Skype-based check-ins in order to reduce the harm and anxiety of, "remotely controlled ankle-shackles" and other CBSA check-ins which treat asylum seekers as criminals (par.12). The recent Supreme Court ruling allowing detainees to access the fundamental right of habeas corpus is a step in the right direction. Simultaneously, it forces Canadians to consider the impacts of crimmigration and that perhaps the larger problem is the detainment of non-criminals in detention centres which are similar to prisons in the first place. 
Still, these solutions offer a bottom-up approach as they attempt to fix the problems of detainment centres and claims processes. They ignore the actual criminalization of migration and the perceived threats of terrorism, criminality and burdens on the welfare system. The role of the media in producing and distributing anti-migrant messages remains impactful and difficult to dismantle. Multiculturalism is at its demise because the security state "demands a cultural policy towards minorities based on cultural homogenisation and forced assimilation. It eschews pluralism and fears of diversity" (Fekete 2004, p.21). However, it is important to be critical of the romanticism multiculturalism policy imposes; it is vital to recognize and encourage cultural difference, yet the very real consequences racism as a social construction and cultural difference have, need not to be ignored and instead to be tackled and prevented systemically. This would leave little room to prioritize security over liberty and protect the racialized 'other' from dehumanization. The role of politicians and the media in enacting membership theory shape the conjunction of criminal and immigration law, which leads to the naturalization of detention and expulsion of those deemed to be future threats.

The increasing consciousness of who belongs and does not belong in society will continue to create fear of the other, socially excluding and out casting them, while violating their inalienable human rights. The criminalization of racialized migration and the root causes for the securitization of borders must be challenged and changed. This includes the messages and information being communicated to Canadians through the mass media both about migrants and the consequences of increased securitization, such as detention centres. Sensationalist coverage and moral panics that associate migrants with crime and crisis must change in order to build legitimate opposition to polices rooted in crimmigration. Though third parties, such as academics, can share and teach information highlighting "not to believe everything in the media", the issue lies at the heart of 
media coverage that pushes the hegemonic crimmigration agenda. The realist policy frame that currently depicts migrants as a threat to society must shift to a human rights-based approach with respect, dignity, and empathy towards migrant communities.

\subsection{Strengths \& Limitations}

There remains a vast literature that links political, ideological and media discourses to the increased securitization of borders. This descriptive and analytical literature review aims to provide an in-depth view on a highly prevalent issue in our society. This type of research can be used to create new research questions, analyze policies, and result in reflective proposals to change such policies. This research can create links between the ways hegemonic discourses in society effect policies that Canadians have a consensus to. It can reveal unspoken or unacknowledged aspects of human behaviour, making salient hidden and dominant discourses that keep migrants marginalized. It aims to enable positive social change, critically challenging traditional theory, policy and practice. Further, as someone with a background in Criminology and a minor in Psychology, I have a good sense of knowledge on the criminalization process, mental health impacts, and the links between the two. This research is also unique because it includes a section focusing on the media's role in reporting these sources. Canadians are aware these centres exist, but this research will help shed some light on what the general person is being told about them and the conditions within them.

This research cannot determine a cause and effect relationship between political, ideological and media discourses and border securitization methods, such as detention centres as the content analysis is unable to decode the messages Canadians are being told about detention centres. The current scope of this research can simply analyze what it is being said about them, not how it is being interpreted or the impacts these messages have on Canadians' view on detention 
centres, migration, and immigration policies. This is especially true given that there is little media attention towards detention centres to begin with, making it difficult to find media coverage that is up to date or transparent. However, this is an important observation about the media coverage of detention centres as it displays the lack of factual knowledge being communicated to Canadians.

\subsection{Future Research}

Future research should include a more in-depth focus on the messages Canadian media provides to readers. Studies to determine the ways in which readers decode messages in the media can be conducted through qualitative research using interviews and surveys. In addition, research to determine the demographic of Canadians who read or watch Canadian media would play an important role to understand which types of Canadians receive their knowledge on detention centres and migration concerns through the media. In the field of Crimmigation, studies should include more attention on alternative to detention programs such as the CAP model. Studies to determine their long-term effectiveness should be conducted in more detail. Finally, there remains a lack of literature about membership theory and the role of the government and media in creating abstract criteria that determines who is, is not, can, and cannot be a member protected under the social contract. 


\title{
References
}

\author{
Media Articles
}

Bensadoun, E. (2019, July 07). How immigration detention centres work in Canada. Retrieved from https://www.ctvnews.ca/canada/how-immigration-detention-centres-work-in-canad a-1.4497688

Browne, R. (2019, June 29). How Canada reduced the number of children held in immigration detention. Retrieved from https://globalnews.ca/news/5430731/canada-migrant-childrenimmigration-detention/

CBC Radio. (2019, July 08). Separation of families at Canadian border is creating 'invisibly detained children': advocate. Retrieved from https://www.cbc.ca/radio/thecurrent/thecurrent-for-july-8-2019-1.5203506/separation-of-families-at-canadian-border-is-creatinginvisibly-detained-children-advocate-1.5203508

CityNews. (2019, July 08). Canadian immigration detention explained. Retrieved from https://toronto.citynews.ca/video/2019/07/08/canadian-immigration-detention-explained/

CTV Montreal. (2019, May 15). Fifty groups unite to speak out against new refugee detention centre in Laval. Retrieved from https://montreal.ctvnews.ca/fifty-groups-unite-to-speakout-against-new-refugee-detention-centre-in-laval-1.4422543

Harris, K. (2019, May 13). Supreme court says migrants can bring detention challenge to judge. Retrieved from https://www.cbc.ca/news/politics/supreme-court-immigration-refugee-de tention-1.5130676

Keung, N. (2018, June 27). Canada slammed for 'culture of secrecy' over immigration detention. Retrieved from https://www.thestar.com/news/gta/2018/06/27/canada-slammed-for-cult ure-of-secrecy-over-immigration-detention.html

Magder, J. (2019, July 16). Activists step up protests of planned Laval detention centre for migrants. Retrieved from https://montrealgazette.com/news/local-news/activists-step-upprotests-of-planned-laval-detention-centre-for-migrants 
Milton, J. (2019, June 25). This is a prison, no matter what you call it. Retrieved from https://briarpatchmagazine.com/articles/view/this-is-a-prison-no-matter-what-you-call-it

Molnar, P., \& Silverman, S. J. (2018, July 05). Canada needs to get out of the immigration detention business: opinion. Retrieved from https://www.cbc.ca/news/opinion/immigratio n-detention-1.4733897

Silverman, S. J., \& Aiken, S. (2019, May 22). A world without immigration detention is possible. Retrieved from https://theconversation.com/a-world-without-immigration-detention-is-po ssible-116626

Wright, T. (2019, July 14). Concerns mount over 'criminalization' of detained migrants in Canada. Retrieved from https://www.thestar.com/news/canada/2019/07/14/concerns-mount-overcriminalization-of-detained-migrants-in-canada.html?utm_source=Twitter\&utm_medium =SocialMedia\&utm_campaign=600pm\&utm_campaign_id=NationalNews\&utm_content =oncerns-mount-over-criminalization-of-detained-migrants-incanada\&utm_source=faceb ook\&source=the $\% 20$ toronto $\% 20$ star\&utm_medium=SocialMedia\&utm_campaign=\&utm _campaign_id=\&utm_content= 


\section{Works Cited}

Amin-Khan, T. (2015). Security and its impact on migrants and refugees. In, Immigrant Experiences in North America: Understanding Settlement and Integration, eds. H. Bauder and J. Shields, pp 118-143, Toronto: Canadian Scholars' Press

Ashutosh, I. (2011). South Asians in Toronto: geographies of transnationalism, diaspora, and the settling of differences in the city. South Asian Diaspora, 4(1): 95-109

Bigo, Didier. (2002). Security and immigration: toward a critique of the governmentality of unease. Alternatives: Global, Local, Political. 27: 63-92.

Caidi, N., \& Allard, D. (2005). Social inclusion of newcomers to Canada: an information problem? Library \& Information Science Research 27: 302-324

Chairperson's Guideline 2, I. and R. B. of. (2010, October 1). Chairperson guideline 2: detention. Retrieved from https://irb-cisr.gc.ca/en/legal-policy/policies/Pages/GuideDir02.aspx

Chaudhary v. Canada, 2015 ONCA 700 (CanLII), Canada: Courts of Appeal, 20 October 2015

Clark, A. (2007). Understanding community: A review of networks, ties and contacts. Real Life Methods Working Papers. 1-39

Cleveland, J. \& Rousseau, C. (2013). Psychiatric symptoms associated with brief detention of adult asylum seekers in Canada. The Canadian Journal of Psychiatry, 58(7): 409-416

Cole, D. (2016, March 10). Stop the indefinite detention of migrants in Canada. The Toronto Star. Retrieved from https://www.thestar.com/opinion/commentary/2016/03/10/stop-the-indef inite-detention-of-migrants-in-canada-cole.html

Dawson, C. (2014). Refugee hotels: the discourse of hospitality and the rise of immigration detention in Canada. University of Toronto Quarterly, 83(4): 826-846

Durlauf, S. N. (1997). The Memberships theory of inequality: ideas and implications. Santa Fe Institute, 1-30

Fekete, L. (2004). Anti-Muslim racism \& the European security state. Race and Class, 46(1): 3- 
Friedkin, N.E. (2004). Social cohesion. Annual Review of Sociology 30: 409-425

Galabuzi, G.E., Teelucksingh, C. (2010). Social cohesion, social inclusion, social capital. Region of Peel Immigration Discussion Paper: 1-37

Hauptman, S. (2013). Criminalization of immigration: The post 9/11 moral panic. Retrieved from https://search-proquest-com.ezproxy.lib.ryerson.ca

Ibrahim, M. (2005). The securitization of migration: A racial discourse. International Migration, 43(5): 163-187

IDC Coalition (2018). There are alternatives to prevent unnecessary immigration detention. Retrieved from https://idcoalition.org/cap/

Immigration and Refugee Protection Act, SC 2001, c 27, <http://canlii.ca/t/52hdn> retrieved on 2018-11-08

Karyotis, G. (2011). The fallacy of securitizing migration: elite rationality and unintended consequences. In Security, Insecurity and Migration in Europe. Eds. G. Lazaridis, 13-30, Farnham: Ashgate

Kozey, K. N. (2015). Collective efficacy, threat, and urban change: examining social control forces in areas of gentrification. UMI Dissertation Publishing:1-149

Magalhaes, L., Carrasco, C., \& Gastaldo, D. (2010). Undocumented migrants in Canada: a scope literature review on health, access to services, and working conditions. Journal of Immigrant and Minority Health 12(1): 132-51

Menjivar, C. (2014). Immigration law beyond borders: externalizing and internalizing border controls in an era of securitization. Annual Review of Law and Social Science, 10, 353-369

Mountz, A., Coddington, K., Catania, R.T., Loyd, J.M. (2012). Conceptualizing detention: mobility, containment, bordering, and exclusion. Progress in Human Geography, 37(4): $522-541$

Social Development Canada. (2010, March 30). Balanced reforms planned for Canada's asylum system. Retrieved from https://www.canada.ca/en/news/archive/2010/03/balanced-reform s-planned-canada-asylum-system.html 
Singh v. Minister of Employment and Immigration, [1985] 1 S.C.R. 177

Stumpf, J. (2006). The crimmigration crisis: immigrants, crime, and sovereign power. American University Law Review, 56(2): 368-418

Toğral, B. (2011). Convergence of securitization of migration and 'new racism' in Europe: rise of culturalism and disappearance of politics. In Security, Insecurity and Migration in Europe, eds. G. Lazaridis, 219-238, Farnham: Ashgate

UN General Assembly. (1948). Universal Declaration of Human Rights (217 [III] A)

Zhou, S. (2014, December 18). Racism in Stephen Harper's Canada. Jacobin Mag. Retrieved from https://www.jacobinmag.com/2014/12/racism-in-stephen-harpers-canada/

Zhuang, Z.C. (2015). Construction and reconstruction of ethnicity in retail landscapes: case studies in the Toronto area. Journal of Urban Design 20(5): 677-697 